\title{
Humanism and Sustainable Development
}

\author{
Marc D. Davidson | ORCID: 0000-0003-1707-5423 \\ Radboud Centre for Philosophy and Society, Radboud University, \\ Nijmegen, The Netherlands \\ marc.davidson@ru.nl
}

\begin{abstract}
Just as other philosophies of life, humanism has to position itself in the societal debate on sustainability. In this article, various tendencies in humanism are discussed that may have contributed to our disturbed relationship with our environment. At the same time, it is also shown that humanism can do without these tendencies and that humanism has a unique voice to offer in the sustainability debate. Because humanists do not believe in a metaphysical afterlife, but instead believe that life only continues here on Earth, humanists in particular have a reason to ensure that the projects to which we contribute and which we cherish have the opportunity to continue to flourish in the future. Without the prospect of a sustainable development, our ability to attach meaning to our present lives diminishes, at least if we are looking for secular sources of meaning.
\end{abstract}

\section{Keywords}

humanism - self-transcendence - sustainable development - human project ecohumanism

\section{Introduction}

Ever since the emergence in the Western world of public debate on our disturbed relationship with our environment (see e.g. Carson, 1962), there has been debate as well on how philosophies of life either have contributed to the problem or can be part of the solution (see e.g. Taylor and Kaplan, 20o8; Jenkins and Bauman, 2009; Jenkins et al., 2016; Ives and Kidwell, 2019). Lynn White (1967) offered the seminal paper on this topic, arguing the ecological crisis to be 
largely related to the 'Christian dogma of man's transcendence of, and rightful master over, nature'. White also discussed alternative Christian views, however, such as the teachings of Saint Francis of Assisi and alternative (non-Western) philosophies of life with different views on man's relation to nature. Today, both individuals adherents to the various philosophies of life and their representative bodies are confronted with the question how to position themselves in the societal debate on sustainability and environmental problems in general (see e.g. Clugston and Holt, 2012).

The purpose of this article is to investigate humanism in particular. Does humanism has a distinctive perspective and source of inspiration to offer or has humanism to put on penitential robes instead? So far, the humanistic voice in the environmental debate has been hardly distinctive. In 2015, the Humanists International adopted at their General Assembly the following 'General Statement of Policy': "We realise that we are all totally dependent on the natural world for our life and well-being. Furthermore we acknowledge an obligation to bequeath to our descendants an earth that offers as good or better an environment for living as we enjoy." The 2019 'Reykjavik Declaration on the Climate Change Crisis' broadened the perspective of the beneficiaries of environmental policy: "We recognize ... that climate change will adversely affect human communities, non-human animals and natural ecosystems." To endorse or express these statements, however, one does not have to be a humanist in particular. The purpose of this article is to show that there are ample points of grip for a uniquely humanistic voice in the sustainability debate.

The setup of this article is as follows. In Section 2, I will first explain the core values of humanism and why at first sight they logically seem to lead to the goal of sustainability. In Section 3, I will moreover explain why sustainable development - contrary to popular thought - is a typically human endeavor, instead of being 'natural', and that the assumption that we are able to develop sustainably is pre-eminently a humanistic idea. In Section 4, I will discuss two sources of friction between humanism and sustainability that have been voiced in the past and show how they can be resolved. These sources of friction are the anthropocentrism and hubris that various authors, such as Ehrenfeld (1978), presume to be characteristic of humanism and presume to lie at the roots of our ecological crisis. In Section 5 , I show that intergenerational justice, which often has been offered as a motive for sustainable development, is philosophically and psychologically weak, while in Section 6 I argue that a stronger motive originates in the human need for self-transcendence and meaning in life. The latter motive, however, has eroded with modern individualism and the modern focus on personal fulfillment (Section 7) that are also characteristic of humanism (Section 8). In Section 9, I argue that it is exactly this motive related to meaning in life which offers a unique voice for humanists in the sustainability debate. 


\section{Humanism and Sustainability at First Glance}

Humanism is a philosophy of life with roots going at least as far back as the Ancient world (Norman, 2004; Copson, 2015). Although modern humanism leaves room for a diversity of interpretations, the following three ideas can be considered as constitutive (Derkx, 2011; Copson, 2015). First, the idea that any philosophy of life is the product of human thought and remains a product of the context in which it originated. Humanists therefore accept and acknowledge that any philosophy of life, including humanism itself, is open to criticism and can be adapted based upon new information and insights; we can never appeal to metaphysical, unshakable truths to back up our positions. Doubt, awareness of the fallibility of one's own thoughts and open-mindedness to other opinions are therefore central to humanism; dogmatism, on the other hand, is alien to it. Most humanists therefore consider themselves atheists, although Christian humanism exists as well (Derkx, 2011). According to the Humanists International, however, "Humanism is not theistic, and it does not accept supernatural views of reality." Second, the idea that each person should consider and regard all others as moral equals to be treated with equal respect. Therefore, humanists emphasize the importance of individual freedom, autonomy and personal responsibility. Humanists might disagree, however, whether our moral duties to our fellowmen are foremost negative, i.e. duties of noninterference, or also positive, i.e. duties to help others in need to lead decent and dignified lives. Humanists involved in humanitarian aid of course adhere to the second point of view. Third, the idea that we should use our freedom to develop ourselves and achieve personal fulfillment. We should take responsibility for our own lives, develop our capacities and our own views regarding the kind of life we wish to live. This responsibility in particular distinguishes humanism as a philosophy of life from simply having the doubt of a philosopher or scientist (first core idea) or having liberal or libertarian political views (second core idea). In this context, humanists often refer to Socrates' statement that 'the unexamined life is not worth living' (see Plato's Apology, section 32A) and to the glorification of the human capacity for free choice noted by the Renaissance philosopher Giovanni Pico della Mirandola (1486). In the humanistic spirit of Socrates and Aristoteles, Martha Nussbaum advocates education that not only offers the intellectual means to pursue one's goals, but also enables one to think critically and be ambitious about alternative goals (2010: 137). Humanists in

1 Source: https://humanists.international/what-is-humanism/. 
particular believe we have a duty to lead the chosen life because they reject the idea of an afterlife: this life on earth is the only life we have.

Given these points of departure there appears to be a self-evident connection between humanism on the one hand and environmental protection and sustainable development on the other (Hinchman, 2004; d' Orville, 2019). Sustainable development has been defined by the World Commission on Environment and Development as "development that meets the needs of the present without compromising the ability of future generations to meet their own needs" (WCED, 1987). If human wellbeing and concern about our fellow humans is central to humanism, then this would include the wellbeing of future generations as well. Respecting the autonomy of future generations to lead fulfilling lives according to their own life plans and caring about their wellbeing implies bequeathing them an environment in which their options remain as open as possible. The Millennium Ecosystem Assessment (MEA, 2005) has mapped out the myriad links between human wellbeing and healthy ecosystems as they provide a wide variety of benefits to people, including food, natural fibers, a steady supply of clean water, regulation of pests and diseases, medicinal substances, recreation, and protection from natural hazards such as floods. The self-fulfillment envisaged by humanism is multi-facetted, moreover, and goes beyond mere material consumption. It includes being able to marvel at the complexity and beauty of the natural world, and an awareness that much about nature is still unknown to us; that the variety of benefits offered by natural ecosystems include spiritual and cultural services, such as providing a sense of continuity and understanding of our place in the universe (de Groot, 1992: 121-123). Concern about the natural environment is therefore reflected, for example, in the third Humanist manifesto of the American Humanist Association (2011), according to which humanists maintain that it is "a planetary duty to protect nature's integrity, diversity, and beauty in a secure, sustainable manner." The 2002 Amsterdam Declaration of the International Humanist and Ethical Union states that humanism "recognises our dependence on and responsibility for the natural world."

\section{Sustainable Development as a Typically Human Endeavor}

Particularly over the last two centuries, mankind has experienced a remarkable development. World population has grown from one billion in 1800 to seven billion today, while this has been combined with an increase in per capita food production. Between 1800 and 2010, global average life expectancy at birth increased from less than thirty to almost seventy years (Riley, 2005; 
Maddison, 2001). Over the same period, the world average per capita GDP increased tenfold (Maddison, 2001). Despite this remarkable development, further development is required, since there are still many people unable to meet their basic needs. Seven hundred million people are chronically undernourished, foremost in developing countries. Although this number has been declining over the last few decades, it has been slowly increasing since 2014 (FAO, 2020).

It is unlikely, however, that further development can be sustained along the path followed in the past. The large-scale burning of fossil fuels since the industrial revolution is leading to dangerous interference with the Earth's climate (IPCC, 2O21). There is large-scale deforestation and desertification, while global biological diversity is rapidly declining (MEA, 2005; IPBES, 2019). We are not only depleting natural resources, such as fossil fuels, but minerals as well. It therefore goes without saying that humanity is presently asking too much of Planet Earth. According to Rockström et al. (2009), humanity has already overstepped a number of planetary boundaries that define the safe operating space with respect to the Earth's biophysical system. A further development along the path of the past will therefore mean that future generations will lack the resources for further economic growth. Some researchers have even predicted a collapse of civilization in a 'business-as-usual' scenario (Meadows et al., 1972; 1992).

Although the present path of development of the human species is unsustainable, it can hardly be considered unnatural in the sense of being at odds with the development paths of non-human species. It is true that in contrast to the human species other species generally live in dynamic equilibrium with their environment. This equilibrium, however, entails a continuous struggle for existence, as Darwin called it, i.e. a continuous competition for resources accompanied by high birth and death rates. Only if a species develops a new advantage relative to other species can it temporarily live in abundance and increase in population. When the population becomes too large and resources consequently become depleted, the species will once again be thrown back to the level of a struggle for existence. So far, mankind does not differ from other species in this natural cycle, nor in the scale of its influence: billions of years ago, during the Proterozoic, blue algae increased the atmospheric concentration of oxygen to such a level as to trigger the massive and global extinction of anaerobic bacteria and algae for which oxygen is toxic. In the present age, it is mankind that, owing to its intelligence, has an advantage over other species. Particularly over the last centuries, mankind has been living in relative prosperity and multiplied accordingly. As mentioned, however, the limits to growth in population and material wellbeing are clearly showing. We thus 
also face the risk of an end to the Anthropocene as the geological era is called in which humankind is leaving an indelible mark on Earth's geology (Crutzen, 2006).

A sustainable development, whereby humanity permanently maintains its quality of life well above the level of a struggle for survival, will therefore be a typically human endeavor. Rather than a return to a natural process, it will be an accomplishment unprecedented in nature as it will require a self-imposed temperance in both procreation and consumption. ${ }^{2}$ Achieving a sustainable development will therefore pre-eminently require an appeal to human capacities. First, the capacity to oversee the consequences of our actions, even though these consequences extend far in space and time, far beyond our direct field of vision. Second, the capacity to be free in our choices: although at present we are essentially not behaving differently from other organisms, we are free to choose for a sustainable development; the ecological crisis is not a necessity. To make different choices, however, we need to understand ourselves and recognize our inner motivations. Third, the capacity to act from inner values: we are capable of caring about our fellowmen, here and now, but also further away in space and time, and caring about non-human nature. The idea that we humans possess these capacities, that we have no fixed nature but can choose our future by exercising our freedom, is pre-eminently a humanistic idea (Hinchman, 2004; American Humanist Association, 2011).

Anthropocentrism and Hubris

Doubts have been raised, however, as to whether humanism is compatible with the cultural shift required for a sustainable development. Humanism has been criticized, for example, for being anthropocentric (see Ehrenfeld, 1978; Soper, 1986; Stanley, 1995). Anthropocentrism is the view that only humans deserve moral consideration and that the sole value of non-human life therefore lies in it being instrumental to human wellbeing. Although humanism rejects the idea of a divine ordering of nature, such as the biblical idea that God has given nature to mankind to be used as a resource (see also White, 1967), it is deemed

2 Particularly in the industrialized world a demographic transition has taken place whereby the fertility rate has gone down to replacement level, a transition that had little to do with concern about the welfare of future generations. Nevertheless, the demographic transition shows man's ability for self-imposed temperance. In the period 2010-2014, however, globally still $44 \%$ of all pregnancies was unintended (Bearak et al., 2018). 
to have inherited the idea from the Renaissance and the Enlightenment that mankind is unique in its distinctively human capacities. From René Descartes humanism is considered to have inherited the idea that non-human life lacks a mind or soul and are therefore merely automata. According to Immanuel Kant, only humans as rational beings are ends-in-themselves, reducing nonhuman life to things of instrumental value only. This human-centered world view is certainly expressed by Principle 1 of the Rio Declaration of the United Nations Conference on Environment and Development (1992): "Human beings are at the centre of concerns for sustainable development. They are entitled to a healthy and productive life in harmony with nature." (see also Brundtland, 1987:46).

Many philosophers have rejected anthropocentrism by arguing that human rationality is an untenable criterion for moral considerability. Utilitarians, such as Jeremy Bentham (1789) and Peter Singer (1974), have argued that what matters morally is the capacity to experience pain and happiness, a capacity not only possessed by humans but by other animals as well. Deontologists, such as Tom Regan (1983), have argued that all 'experiencing subjects of a life'animals with beliefs, desires, perception, memory, emotions, a sense of future, and the ability to initiate action-are ends-in-themselves and therefore deserve moral consideration. Other philosophers have argued that all 'teleological centres of life', i.e. all individual living entities, ought to be given moral consideration (see Taylor, 1986; Goodpaster, 1978), while some deontologists attribute intrinsic value to ecological wholes such as species, populations, biotic communities, and ecosystems (see e.g. Leopold, 1949; Callicott, $1980 ; 1989)$. It is not only philosophers who have argued for different criteria for moral considerability; in recent decades, biologists such as Frans de Waal (2007) have shown that capacities formerly assumed to be uniquely human are possessed by non-human organisms as well.

Although there is good reason to reject anthropocentrism, this criticism is not fatal to humanism itself (Bookchin, 1995; Eckersly, 1998; Hinchman, 2004). None of the central characteristics of humanism described in Section 2 depend upon an anthropocentric worldview. Most humans (with for example the exception of small infants) are able to act on moral principles and are therefore morally responsible for their acts, i.e. they are moral agents (or moral subjects). According to humanism, our human capacities impose moral duties on us, such as respecting the autonomy and personal fulfillment of others. This does not delineate the realm of moral patients (or moral objects), however, i.e. the realm of entities deserving moral consideration. Therefore, even if humanism were to assume that only humans can be moral agents, this does not lead to the view that only humans are moral patients, i.e. anthropocen- 
trism. ${ }^{3}$ Various humanists have therefore questioned the anthropocentric tendencies from the inside, such as Wouter Achterberg (1992) who advocated 'a humanism with less arrogance', i.e. a humanism that does not consider mankind as the center of natural reality in either a moral or practical sense. Andrew Brennan (1988a, b) has advocated 'ecological humanism' on the basis of a communitarian view. According to this view, human beings pursue the developmental ideal of becoming fully integrated persons within community contexts, communities that also include our natural surroundings: "Ecological humanism argues that it is part of living well, of living a good human life that our attitude to the natural world in which such lives are led to one of respect, wonder and care. Such an attitude contrasts with one which thinks of nature in purely instrumental terms - as no more than our life-support system, or as a source of goods to be plundered at will." (Brennan, 1988b). ${ }^{4}$

Apart from an anthropocentric worldview, humanism is held to have inherited the hubris of the Enlightenment, moreover, particularly Francis Bacon's view that through scientific and technological progress nature could be controlled and dominated to improve the human condition. According to Ehrenfeld (1978: 16-17), for example, humanism has as fundamental assumptions that "all problems are soluble by humans, that many problems are soluble by technology, that problems not soluble by technology or technology alone have solutions in the social world (of politics, economics, etc.), that finite and limited resources have substitutes, and that humans will apply themselves and work together for a solution before it is too late". Stanley (1995) discerns this same (technological) optimism in the paradigm of ecosystem management. According to these critics, such ecosystem management will fail, since it is this hubris that is held to lie at the root of our ecological crisis.

Although there will be humanists who indeed share optimism and confidence in technology, such as humanists who adhere to 'ecomodernism' (AsafuAdjaye et al., 2015; Symons, 2019), there will also be humanists who do not. The ideas central to humanism as described in the introduction are also com-

3 The Humanists UK have a specific campaign about animal welfare, seeing "compassionate attitudes to animal suffering as a hallmark of a humane society": https://humanists.uk/ campaigns/public-ethical-issues/animal-welfare/.

4 See Morris (2012) for a discussion of the ecological critique of industrial capitalism by Lewis Mumford, René Dubos and Murray Bookchin. Morris calls them 'pioneers of ecological humanism', although these thinkers did not themselves use this label. Hinchman (2004) suggests Aldo Leopold's $A$ Sand County Almanac as the paradigm case of environmental thought with roots in humanistic approaches. 
patible with a view of nature as fragile, that technological solutions may bite back through unforeseen rebound effects (Tenner, 1996), and that we should therefore adopt a precautionary approach. In fact, these two opposing views regarding the perils and promises of technology and human interference with the natural world correspond to two 'myths' of nature that are discerned in the cultural theory of risk (see e.g. Douglas and Wildavsky, 1982; Thompson et al., 199o; Adams, 1995). According to the cultural theory of risk, faced with incomplete and often contradictory information, people perceive the world through a 'filter' that influences both the way issues are defined and preferences as to how they should be handled. The essence of cultural theory is that there is no 'truth' or 'untruth' in any of these filters; the filters lie beyond the possibility of rational discussion. Myths regarding nature's resilience or optimism versus pessimism concerning technology's promises cannot be negated by scientific insights, since the myths by definition start where the eye of science as yet does not reach. Given the central ideas and attitudes of humanism, there is no reason to assume that humanism is linked solely to one particular myth of nature and technology. The central idea of humanism that we are responsible for our own lives and choices does indeed imply a certain optimism, but not necessarily an optimism regarding technology and nature's resilience. The only worldview or myth of nature incompatible with humanism is that of fatalism, i.e. the view that what will happen is inevitable. In fact, Ehrenfeld himself appears to believe a humanism is possible that is less 'arrogant': "when the inappropriate religious elements have been removed, humanism will become what it ought to be, a gentle and decent philosophy and a trustworthy guide to nondestructive human behavior" (Ehrenfeld, 1978: 5).

\section{5}

\section{Respect for Future Generations}

In the previous sections, two reasons have been discussed why in the past humanism has been criticized in relation to sustainable development: humanism is seen as voicing the anthropocentrism and hubris held to be at the roots of our ecological crisis. A third reason has been discussed far less: with its focus on individual rights, autonomy and personal fulfillment, humanism voices the individualism that lies at the roots of the erosion of the capacity for selftranscendence that is required for sustainable development. In the next section (6), it will be explained that humans need to be embedded in and contribute to something that is larger than oneself, and that a sustainable development is a prerequisite for the fulfillment of this need for self-transcendence. Sections 7 and 8 describe how, since the Enlightenment, a narrowing of vision has 
occurred which erodes our understanding of being a link and partner in a long, intergenerational chain, a narrowing of vision that is also to be discerned in humanism.

In this section, however, it will first be argued that there are philosophical and psychological obstacles to caring about future generations on the basis of their rights to a clean environment and natural resources. First, there is the notorious non-identity problem (Adams, 1972; Parfit, 1976, 1981, 1984): any choice we make regarding the future, such as a choice between a sustainable or unsustainable development, will not only alter the environment in which future generations will live but will inevitably also alter who they will be. If the future develops differently, different people will meet and beget different children. Even if the same people beget children, the time of conception will be different, resulting in children with different DNA and thus a different identity. As Derek Parfit asks us to imagine: "How many of us could truly claim, "Even if railways had never been invented, I would still have been born"?" (1981:115). It is therefore impossible to respect the autonomy of future generations and equally impossible to violate their autonomy. If a future person, let us call her Trudy, lives in a future polluted world, we do not respect her autonomy by making different present choices and thereby creating an unpolluted world in which Bob lives instead of Trudy. The assumption here is that Trudy's life is not so miserable that she would have preferred not to have been born at all. To violate a person's autonomy we must be able to respect that autonomy. We are, however, unable to respect Trudy's autonomy and therefore also unable to violate it. Consequently, we have no moral reason to pursue a sustainable development out of respect for the autonomy of future generations.

Even if there were no non-identity problem and we were able to respect the autonomy of future generations, it might psychologically be difficult to do so (Davidson, 2008). ${ }^{5}$ Although various philosophers and psychologists emphasize the importance of personal contact in people's perceptions of responsibility, there are no future generations to voice their interests today. In the work of Emmanuel Levinas, especially, personal contact with the other-eye to eyeplays an important role (see e.g. Levinas, 1961). According to Levinas, by our nature we try to make the world around us part of ourselves, 'consuming' and enjoying it. We can also fit other people into this agreeable worldview, as long as we are not in direct contact with them. In direct personal contact, however, in the face of the other we finally experience a real other person: something that

5 The following two paragraphs are largely quoted from the author's $\mathrm{PhD}$ thesis (Davidson, 2008: 10-12). 
does not allow itself to be appropriated or consumed, to be made into a mere pleasing experience. We are unprepared for the uniqueness of the other, and thus the other interrupts our egoism, penetrates our self-satisfied world and makes us feel vulnerable. Because this direct contact provides an opportunity to respond, moreover, it also generally forces us to do so. We assume responsibility, and feel it. In short, we cannot ignore the moral pressure ensuing from the presence of the other. Levinas' view is consistent with neuropsychological research which has shown the importance of 'mirror neurons' in the arousal of empathy and therefore the importance of personal experience (Keysers, 2011; Cowan et al., 2014; Robson, 2015). Mirror neurons are brain cells that fire both when perceiving an action and while executing an action.

That the 'face' of the other can exert a moral appeal on us is of course well known to any organization seeking social commitment. Development organizations like Foster Parent Plan (Plan International) know as no other the importance of giving development aid a face. Binding donors to specific children enhances their commitment. Similar considerations apply to the importance of images of victims and interviews in disaster relief campaigns on national television. The same holds, too, for environmental organizations like the World Wide Fund for Nature, with its campaigns showing animals looking straight at the viewer. Through the eyes of the seal, it is not wwF that is appealing to us but the seal itself. Emotions aligned to ideas of fairness, solidarity and empathy are thus activated by the opportunity to put oneself in the position of the other, by identifying with them. The importance of a face is evident. Future generations and their situation, however, by definition we can never see. We cannot establish contact with them, either personally or through third parties. We cannot have a conversation with them and we cannot read their feelings from their face, making authors like Heilbroner (1974), Hardin (1977) and Care (1982) pessimistic about our capacity to be stirred by the interests of future generations (see also Birnbacher, 2009).

To some extent, of course, fiction such as films and literature can establish emotional and cognitive contact with others with whom one does not have face-to-face encounters. A famous example is how Harriet Beecher Stowe's Uncle Tom's Cabin contributed to the abolition of slavery by arousing empathy for slaves among those who did not have first-hand contact with slavery. Philosophers, such as Martha Nussbaum (1997), have championed the importance of literature and art in general, for the arousal of sympathy for others. The spillover of sympathy for fictional characters to actual behavior in real life is disputed, however (Bracher, 2009), although some psychological research suggests its existence (Batson et al., 2012). 
There are, however, other reasons to care about the future that face neither the philosophical problems described above, nor the earlier mentioned psychological barriers. These reasons originate in the human need for self-transcendence and meaning in life. The term 'self-transcendence' may arouse suspicion, particularly among humanists, but is not meant to refer to the belief in a different metaphysical reality or mystical ontology. Instead, what is referred to is simply the human need to be part of or to contribute to something that lies outside oneself (see e.g. Partridge, 1980; Heyd, 1992; Scheffler, 2013). Examples include contributing to family life, the university where one works, writing books, continuation of traditions, or starting a new company. According to psychologists, we humans have a need to place ourselves and our acts in frameworks that are larger than ourselves, that lie outside ourselves. We need to be able to see that larger framework as valuable and we need to be able to contribute to that larger whole, to make a difference, however small (see e.g., Maslow 1968, Frankl 1972, Yalom 1980, Baumeister 1991; Wong, 2016). If we are unable to do so, we may feel alienated and depressed. In other words, we need to see our lives as meaningful. As Abraham Maslow observed $(1968,206)$, "The state of being without a system of values is psychopathogenic, we are learning. The human being needs a framework of values, a philosophy of life, a religion or religion surrogate to live by and understand by, in about the same sense that he needs sunlight, calcium or love". ${ }^{6}$

In philosophy, the importance of self-transcendence lies at the root of the criticism of (ethical) hedonism, the thesis that the experience of pleasure and pain are the only things of ultimate importance. Robert Nozick (1976: 44-45) used his famous thought example of the 'experience machine' as an intuitive argument against hedonism. Few people would be willing to be connected for life to a machine that would give you any experience you desired, such as writing a great novel or caring for your family. Most people agree with Nozick that it is also good in itself "to do certain things, and not just have the experience [as if] of doing them" and "to make a difference in the world" rather than merely to appear to oneself to do so (43-44). Therefore, most people reject hedonism.

The relevance for sustainable development is that self-transcendence and meaning in life generally presuppose the continuation of what we value. Al-

6 Note that in older versions of Maslow's famous hierarchy of needs 'self-actualization' is at the top, but Maslow later put 'self-transcendence' as a motivational capstone above selfactualization (Koltko-Rivera, 2006). 
though there are activities that derive their value from their finiteness and uniqueness, such as a holiday on Bora Bora, most activities we consider meaningful presuppose an open future. It is contradictory to cheer for your favorite team as a devoted supporter, but not to care whether your team ceases to exist if you die yourself. It is equally contradictory to put one's heart and soul into the company one has established, but not to care whether the company goes bankrupt after one's own retirement. Or not to care about the future of your family after your own death. In other words, many activities that give meaning to our lives do so because we contribute to or feel connected to something that survives us. Scheffler (2013:52) calls this the 'afterlife': "without confidence that others will live on after we ourselves have died-many of the things that now matter to us would cease to do so or would come to matter to us less." At a political scale, we find this idea in Edmund Burke's description of society in his Reflections on the revolution in France (Burke, 179o):

[society] is a partnership in all science, a partnership in all art, a partnership in every virtue and in all perfection. As the ends of such a partnership cannot be obtained in many generations, it becomes a partnership not only between those who are living, but between those who are living, those who are dead, and those who are to be born.

Once we consider society as such a partnership and realize that the possibilities for leading meaningful lives in the present depend upon an open future in which future generations can continue the activities, projects and traditions that we consider valuable, then the importance of a sustainable development becomes beyond dispute. An unsustainable development shortens the expiry date of everything we consider valuable. In short: every human being has a need to be embedded in and contribute to something that is larger than oneself, something that outlives oneself. A sustainable development is a prerequisite for this need to be fulfilled, that the future remains open.

Despite the importance of self-transcendence for human wellbeing, a temporal narrowing of vision has occurred since the Enlightenment, which erodes our understanding of being a link and partner in a long intergenerational chain (O'Neill, 1993). Instead, many people in modern (Western) society have started to look for value primarily in themselves and identity, and therefore primarily in their own lives between birth and death. 
Since the Enlightenment, the importance of religion and tradition has diminished with increasing individualization. To the Enlightenment we owe a more rational perspective on reality and being allowed to criticize belief in higher powers. We also owe to the Enlightenment an appreciation of the individual: the idea of man as a rational, autonomous and independent being by nature, with accompanying rights and duties. There is neither divine providence or predestination limiting our individual freedom, nor is there historical or holistic predestination (Udehn, 2002: 340). We are influenced by our historical and cultural setting, but we are free to make different choices, as little are we bound by laws of development of the social groups of which we are part. Neither need we conceive of ourselves merely as matter determined by the laws of nature, or as organisms merely responding to external stimuli. Although we are these as well, we also experience a free will.

Unfortunately, it seems that with the gains in individual freedom the baby has been thrown away with the bathwater. In the Western world, people have not only gained the individual freedom to choose for themselves what they value and how they give meaning to their lives, but have also chosen to look for this meaning primarily in their individual selves. In modern times, according to psychologist Roy Baumeister (1991: 78; see also 1987), a fascination with the self and identity has developed in substitution for lost frames of meaning, a focus on personal identity and personal fulfillment as the source of all value (see also Taylor, 1989; Giddens, 1991). This should not be misinterpreted: the modern fascination with self does not necessarily imply egoism. It is fully compatible with solidarity and respect for other people's autonomy, i.e. the recognition that others, too, have an equally valuable self. It is much less compatible, however, with self-transcendent values, values that are not located solely in one's own or someone else's self, but in shared practices.

This loss of connectedness shows, for example, if we compare Burke's description of society with the famous definition of sustainable development by the Brundtland Commission, as "a development that meets the needs of the present without compromising the ability of future generations to meet their own needs" (Brundtland, 1987). In this phrasing the connection between the generations has been reduced to the causal connection to unknown hikers with whom we share nothing more than the same 'camping site' (Lippit and Hamada, 1977: 293). The future generations about which the Brundtland Commission speaks, could equally have lived on a different planet or a different continent: others who are not partners in generation-transcending projects, traditions and practices, but others towards which we experience duties because we accidently became aware of their existence and the fact that we might potentially harm them; sustainability merely from humanitarianism and acknowl- 
edgement of the autonomy and human dignity of future generations (see also O'Neill, 1993: 27). From this individualistic perspective it would even be better for present generations if there were no future generations, i.e. if we were the last hikers on the camping site. The same interpretation of sustainability as a matter of intergenerational justice is found in other seminal works in the debate on sustainability, such as Solow (1974), Barry (1989) and Weiss (1990).

\section{Individualism and Humanism}

The same modern individualism and fascination with the self observed by Baumeister can be discerned in humanism, particularly in the humanist ideal of personal fulfillment. This ideal is generally attributed to the acknowledgment of our mortality combined with the rejection of a belief in an afterlife, the idea that we as persons would live on as the same person in a different realm after our death. As Andrew Copson (2015) writes in the introduction to the Wiley Blackwell Handbook of Humanism:

there is no reason to suppose that there is anything of us that could endure through death and beyond. (11) ... The humanist view that this life is our only life-acceptance of the finite nature of the human person in time-has consequences for this important notion [of 'the good life']. This life is not merely an episode in our existence-it is our entire existence. We will never develop further as persons than we will develop in this life: there is no future time in which completion may occur.

14

This quote expresses the Epicurean thought that 'When death is there, we are not; when we are there, death is not'. Although the quote does not directly express the idea that we do not have to fear death, since what happens after our death cannot harm us, it does express the idea that what happens after our death cannot benefit us either. Therefore, I should live my life to the fullest and help others live full, happy lives as well.

However, although it is true that neither our physical body nor our mind can survive death, it goes too far to say that death is complete annihilation. As explained in the previous sections, our accomplishments and impacts on the world do not cease to exist when we are no longer around in person to be conscious of these accomplishments. When I die, this article does not cease to be $m y$ article: it ceases to be my article in a legal sense, but I still remain causally responsible for it. In other words, there are many things "of us that 
could endure through death and beyond". All our contributions to the development of the causes, projects and traditions we value will endure beyond our personal involvement. ${ }^{7}$ That we will die as persons is therefore no reason to restrict our focus to personal development and fulfillment. As Heyd observes (1992: 219): "Self-transcendence implies that what happens to our descendants, projects, political aspirations, and social ideals affects $u s$, even after our individual extinction, albeit in a roundabout manner."

In its emphasis on personal fulfillment and self-actualization, humanism has often shown a reluctance to name both the need for and the possibility of selftranscendence. In On Humanism (2004), for example, Norman acknowledges that we find meaning in being able to place our acts in a coherent story, in narratives. Norman goes at length, however, to explain that these are stories of particular individuals, while sailing around the possibility that these stories transcend individuals. However, just as little as humanism is intrinsically linked to the view that only humans have moral value (anthropocentrism) is it intrinsically linked to the view that all value is to be found in the self and personal identity. The humanistic core value of human dignity and the humanistic advocacy of individual freedom do not necessarily entail a restricted individualistic view on what is valuable in life. Humanism is compatible with the acknowledgment of the human need for self-transcendence, the acknowledgment that we human beings identify with matters and projects that lie outside ourselves (Partridge, 1980) and that we extend our existence not only by literal procreation, but also by procreation of our identity through our projects and social ideals (Heyd, 1992). To become more 'enlightened', however, humanism would have to weaken its focus on personal fulfillment and development, and lose its cold feet about speaking for values that transcend the individual, such as the development of humanity as such, and human progress (see also Mantatov et al., 2020). What humanism has to offer is indeed an 'afterlife' as Scheffler (2013) calls it, albeit a secular afterlife.

7 In fact, the Second Humanist Manifesto does observe that "We continue to exist in our progeny and in the way that our lives have influenced others in our culture" (Kurtz and Wilson, 1973). 
In this article, I have investigated the relationship between humanism and the goal of sustainable development. It was shown that a self-evident connection exists between humanism on the one hand and environmental protection and sustainable development on the other, but that frictions exist as well. Humanists long for and strive toward a world of mutual care and concern, and recognize that the availability of natural resources is a prerequisite for achieving individual happiness. Therefore, humanism embraces the aim of a sustainable development to ensure that not only the present, but also future generations will have the natural resources required to lead decent and dignified lives. According to some authors, however, humanism is synonymous with the anthropocentrism and hubris that they deem to lie at the roots of our ecological crisis. In this view, humanism is therefore an obstacle to sustainable development rather than the cure. Other authors, however, have argued that anthropocentrism and hubris are not constitutive for humanism, and have advocated an ecological humanism.

In this article a third source of friction has been discussed that so far has received less attention: humanism's individualism and focus on personal development. On the one hand, the individualistic reasons that are commonly given for sustainable development such as respect for the autonomy of future generations are both philosophically and psychologically weak. Due to the notorious non-identity problem we are unable to respect the autonomy of future generations, while the impossibility of having direct contact with future generations weakens our willingness to transform any duties towards them into actions. On the other hand, humanism's individualism and focus on personal development ignore the motive for care about the far future that is immune to the previous philosophical and psychological problems: the human need for selftranscendence and meaning in life. Human beings need to feel embedded in and contribute to something that is larger than oneself, something that outlives oneself. Modern humanism has been afraid to acknowledge such values outside the self. The emphasis on individual rights and autonomy in humanism is understandable: they offer a line of defense against being forced to live according to other people's value frameworks. Individual rights do not mean, however, that what we value should be restricted to the self; such rights are perfectly compatible with self-transcendent values. Of course, we are born and raised in communities and therefore inherit value frameworks from our surroundings (Bell, 2016). We cannot reinvent ourselves from scratch. Nevertheless, we are free to question our own values and reshape them, which is pre-eminently a central pillar of humanism. 
It is this human need for self-transcendence and meaning in life that offers humanism the opportunity for a unique and distinctive voice in the sustainability debate. Exactly because humanists do not believe in a metaphysical afterlife, but believe that life only continues here on Earth, humanists in particular have a reason to ensure that the projects to which we contribute and which we cherish have the opportunity to continue to flourish in the future. Without the prospect of a sustainable development, our ability to attach meaning to our present lives diminishes, at least if we are looking for secular sources of meaning. A humanism that focuses less on autonomy and fulfillment of the individual, and more on the value of the human project as such, a humanism that focuses less on self-actualization and more on self-transcendence, thus offers both a secular source of meaning and a strong motive for sustainable development. Is there life after death? Only if we protect it ourselves.

\section{References}

Achterberg, W. 1992. Humanism without arrogance: modern humanism and ecocentrism (in Dutch). Wageningen: Landbouwuniversiteit Wageningen.

Adams, J. 1995. Risk. London: University College London Press.

Adams, R. 1972. 'Must God create the best?' The Philosophical Review 81(3): 317-332;

American Humanist Association. 2011. 'Humanist manifesto III: Humanism and its aspirations'. Humanist 71(4): 39-39.

Asafu-Adjaye J, Blomqvist L, Brand S, et al. (2015) An Ecomodernist Manifesto. Oakland, CA: Breakthrough Institute.

Barry, B. (1989). 'The Ethics of Resource Depletion.' In: Democracy, Power and Justice: Essays in Political Theory. Oxford: Clarendon Press, ${ }^{111-525}$.

Batson, C.D., Chang, J., Orr, R., \& Rowland, J. (2002). Empathy, attitudes, and action: Can feeling for a member of a stigmatized group motivate one to help the group?. Personality and Social Psychology Bulletin, 28(12), 1656-1666.

Baumeister, R.F. (1987). How the self became a problem: A psychological review of historical research. Journal of personality and social psychology, 52(1), 163.

Baumeister, R.F. 1991. Meanings of life. Guilford Press.

Bearak, J., Popinchalk, A., Alkema, L., \& Sedgh, G. (2018). Global, regional, and subregional trends in unintended pregnancy and its outcomes from 1990 to 2014: estimates from a Bayesian hierarchical model. The Lancet Global Health, 6(4), e38oe389.

Bell, D. 2016. 'Communitarianism'. The Stanford Encyclopedia of Philosophy (Summer 2016 Edition), Edward N. Zalta (ed.), URL = https://plato.stanford.edu/archives/sum 2016/entries/communitarianism/. 
Bentham, J. 1789. An Introduction to the Principles of Morals and Legislation. Garden City: Doubleday (1961).

Birnbacher, D. 2009. 'What motivates us to care for the (distant) future'. In: Gosseries, A. and L.H. Meyer (Eds.). Intergenerational Justice. Oxford: Oxford University Press, 273-30o.

Bookchin, M. 1995. Re-enchanting Humanity: A Defense of the Human Spirit Against Antihumanism, Misanthropy, Mysticism and Primitivism. New York: Cassell.

Bracher, M. (2009). How to Teach for Social Justice: Lessons Form" Uncle Tom's Cabin" and Cognitive Science. College English, 71 (4), 363-388.

Brennan, A. 1988a. Thinking about nature. Athens: University of Georgia Press.

Brennan, A., 1988b, 'Ecological Humanism'. In: A. Vlavianos-Arvanitis (Ed.). Biopolitics, The Bio-environment: Bios in the next millennium, Volume II, Proceedings from the Second в Iо International Conference. Athens, Greece. Available at: http://biopoli tics.gr/biowp/wp-content/uploads/2013/o4/ah-brennan.pdf

Brundtland, G.H. 1987. Report of the World Commission on environment and development: our common future. New York: United Nations.

Callicott, J.B. 1980. 'Animal Liberation, A Triangular Affair'. Environmental Ethics 2: 311338.

Callicott, J.B. 1989. In Defense of the Land Ethic. Albany, NY: State University of New York Press.

Care, N.S. 1982. 'Future Generations, Public Policy and the Motivation Problem'. Environmental Ethics 4(3): 195-213.

Carson, R. 1962. Silent Spring. Boston: Houghton Mifflin.

CIA, 2016, The World Factbook 2015-16. Washington, DC: Central Intelligence Agency.

Clugston R. and S. Holt (eds.) 2012. Exploring Synergies between Faith Values and Education for Sustainable Development. Earth Charter International and Earth Charter Center for Education for Sustainable Development at UPEACE.

Copson, A. 2015. 'What Is Humanism?' In: A.C. Grayling (Ed.). The Wiley Blackwell Handbook of Humanism. West Sussex: John Wiley \& Sons, 1-34.

Cowan, D.G., Vanman, E.J., \& Nielsen, M. (2014). Motivated empathy: the mechanics of the empathic gaze. Cognition and Emotion, 28(8), 1522-1530.

Crutzen, P.J. 2006. 'The "anthropocene"'. In: E. Ehlers and T. Krafft (Eds.). Earth system science in the anthropocene. Springer Berlin Heidelberg, 13-18.

Davidson, M.D. 2008. Arguing about climate change. Amsterdam: Amsterdam University Press.

De Groot, R.S., 1992. Functions of Nature: Evaluation of Nature in Environmental Planning, Management and Decision Making. Groningen: Wolters-Noordhoff.

De Waal, F. 2007. Chimpanzee politics: Power and sex among apes. Baltimore:Johns Hopkins University Press.

Della Mirandola, P. 1486. Pico della Mirandola: Oration on the Dignity of Man: A 
New Translation and Commentary (2012). Cambridge: Cambridge University Press.

Derkx, P.H.J.M. 2011. Humanisme, zinvol leven en nooit meer 'ouder worden'. Een levensbeschouwelijke visie op ingrijpende biomedisch-technologische levensverlenging. Brussel: AsP/VUBPRESS/UPA.

Douglas, M. and A.B. Wildavsky. 1982. Risk and Culture: An essay on the selection of technical and environmental dangers. Berkeley: University of California Press.

Eckersley, R. 1998. 'Beyond human racism'. Environmental Values 7(2): 165-182.

Ehrenfeld, D.W. 1978. The arrogance of humanism. Oxford: Oxford University Press.

FAO. 2020. The State of Food Security and Nutrition in the World 202O. Transforming food systems for affordable healthy diets. Rome, FAO.

Frankl, V. 1972. Der Wille zum Sinn. Bern: Hans Huber.

Giddens, A. 1991. Modernity and self-identity: Self and society in the late modern age. Cambridge: Polity.

Goodpaster, K.E. 1978. 'On being morally considerable'. The Journal of Philosophy 75(6): 308-325.

Hardin, G. 1977. The Limits of Altruism. London: Indiana University Press.

Heilbroner, R.L. 1974. An Inquiry into the Human Prospect. New York: Norton.

Heyd, D. 1992. Genethics: Moral Issues in the Creation of People. Berkeley: University of California Press.

Hinchman, L.P. 2004. Is environmentalism a humanism?. Environmental Values 13(1): $3^{-29}$.

IPCC, 2021: Summary for Policymakers. In: Climate Change 2021: The Physical Science Basis. Contribution of Working Group I to the Sixth Assessment Report of the Intergovernmental Panel on Climate Change [Masson-Delmotte, V., P. Zhai, A. Pirani, S.L. Connors, C. Péan, S. Berger, N. Caud, Y. Chen, L. Goldfarb, M.I. Gomis, M. Huang, K. Leitzell, E. Lonnoy, J.B.R. Matthews, T.K. Maycock, T. Waterfield, O. Yelekçi, R. Yu and B. Zhou (eds.)]. Cambridge University Press. In Press.

IPBES (2019): Summary for policymakers of the global assessment report on biodiversity and ecosystem services of the Intergovernmental Science-Policy Platform on Biodiversity and Ecosystem Services. S. Díaz, J. Settele, E.S. Brondízio E.S., H.T. Ngo, M. Guèze, J. Agard, A. Arneth, P. Balvanera, K.A. Brauman, S.H.M. Butchart, K.M.A. Chan, L.A. Garibaldi, K. Ichii, J. Liu, S.M. Subramanian, G.F. Midgley, P. Miloslavich, Z. Molnár, D. Obura, A. Pfaff, S. Polasky, A. Purvis, J. Razzaque, B. Reyers, R. Roy Chowdhury, Y.J. Shin, I.J. Visseren-Hamakers, K.J. Willis, and C.N. Zayas (eds.). IPBES secretariat, Bonn, Germany. $5^{6}$ pages. https://doi.org/10.5281/zenodo .3553579

Ives, C.D., \& Kidwell, J. (2019). Religion and social values for sustainability. Sustainability Science, $14(5), 1355^{-1362 .}$

Jenkins, W., \& Bauman, W. (Eds.). (2009). The spirit of sustainability: Religion, Ethics and 
Philosophy. (Vol. 3). The Encyclopedia of Sustainability. Great Barrington, MA: Berkshire.

Jenkins, W.J., Tucker, M.E., \& Grim, J. (Eds.). (2016). Routledge handbook of religion and ecology. Routledge.

Keysers, C. The Empathic Brain: How the Discovery of Mirror Neurons Changes Our Understanding of Human Nature (Social Brain Press, 2011)

Koltko-Rivera, M.E. 2006. 'Rediscovering the later version of Maslow's hierarchy of needs: Self-transcendence and opportunities for theory, research, and unification'. Review of general psychology 10(4): 302-317.

Kurtz, P. and E.H. Wilson. 1973. Second Humanist Manifesto. Washington: American Humanist Association.

Leopold, A. 1949. A Sand County Almanac. Oxford: Oxford University Press.

Levinas, E. 1961. Totalité et Infini. Essai sur l'extériorité. La Haye, Nijhoff.

Lippit, V.D., \& Hamada, K. (1977). Efficiency and equity in intergenerational distribution. In: Pirages, D.C. Sustainable society: implications for limited growth, $p p .285^{-}$ 299 .

Maddison, A. 2007. The world economy volume 1: A millennial perspective volume 2: Historical statistics. New Delhi: Academic Foundation of the OECD.

Mantatov, V., Mantatova, L. \& Nasibulina, A. (2020). Humanism and environmental ethical frameworks. In UNEsco (2O2O). Humanistic futures of learning. Perspectives from Unesco Chairs and UNITwIN Networks (pp. 34-38). Paris: UnEsco.

Maslow, A. 1968. Toward a psychology of being. New York: Van Nostrand.

MEA (Millennium Ecosystem Assessment). 2005. Ecosystems and Human Well-being: Synthesis. Washington, DC.: Island Press.

Meadows, D.H., Meadows, D.L., Randers, J., and Behrens III, W.W. 1972. The limits to growth: a report to the club of Rome. New York: Universe Books.

Meadows, D.H., D.L. Meadows and J. Randers. 1992. Beyond the limits: global collapse or a sustainable future. London: Earthscan Publications Ltd.

Morris B. 2012. Pioneers of Ecological Humanism. Brighton, UK: Book Guild Publishing. Norman, R. 2004. On humanism. Oxford: Routledge.

Nozick, R. 1974. Anarchy, state, and utopia. New York: Basic books.

Nussbaum, M.C. “The Narrative Imagination.” In: Cultivating Humanity: A Classical Defense of Reform in Liberal Education. Cambridge, MA: Harvard UP, 1997. 85-112. Nussbaum, M.C. 2010. Not for profit: Why democracy needs the humanities. Princeton University Press.

d'Orville, H. (2019). Sustainable Development and New Humanism. In: L. Yang and W. Chan (eds), New Humanism And Global Governance (pp. 3-18). World Scientific Publishing Co., Singapore.

Parfit, D. 1976. 'On doing the best for our children'. In: M.D. Bayles (Ed.). Ethics and Population. Cambridge: Schenkman, pp. 100-115. 
Parfit, D. 1981. 'Future generations: further problems'. Philosophy \& Public Affairs 11(2): $113-172$.

Parfit, D. 1984. Reasons and Persons. Oxford: Clarendon Press.

Partridge, E. 1980. 'Observations: Why care about the future?' Alternative Futures 3(4): 77-91.

Regan, T. 1983. The Case for Animal Rights. Berkeley: University of California Press.

Riley, J.C. 2005. 'Estimates of regional and global life expectancy, 1800-2001.' Population and development review 31(3): 537-543.

Robson, G. (2015). Not Seeing Eye-to-Eye: Social Media, Disembodied Interaction and the Erosion of Empathy. Encountering Empathy, 123-138.

Rockström, J., Steffen, W., Noone, K., Persson, Å., Chapin, F.S., Lambin, E.F., ... \& Nykvist, B. 2009. 'A safe operating space for humanity'. Nature 461(7263): 472-475.

Scheffler, S. (2013) Death and the Afterlife, New York: Oxford University Press.

Singer, P., 1974. 'All Animals Are Equal'. Philosophical Exchange 1(5): 243-257.

Solow, R.M. (1974). Intergenerational equity and exhaustible resources. The review of economic studies, 41, 29-45.

Soper, K. 1986. Humanism and Anti-Humanism. London: Hutchinson.

Stanley, T.R. 1995. 'Ecosystem management and the arrogance of humanism'. Conservation Biology 9(2): 255-262.

Symons, J. (2019). Ecomodernism: Technology, politics and the climate crisis. John Wiley \& Sons.

Taylor, B.R., \& Kaplan, J. (2008). The Encyclopedia of Religion and Nature:Volume 1 and 2. Continuum, London, UK.

Taylor, P.W. 1986. Respect for Nature: A Theory of Environmental Ethics. Princeton NJ: Princeton University Press.

Taylor, C. 1989. Sources of the Self: The Making of the Modern Identity. Cambridge, MA: Harvard University Press.

Tenner, E. 1996. Why Things Bite Back: Technology and the Revenge of Unintended Consequences. New York: Alfred A. Knopf.

Thompson. M., R.J. Ellis and A. Wildavsky. 1990. Cultural theory. Boulder, CO: Westview.

Udehn, L. 2002. Methodological individualism: Background, history and meaning. Routledge.

Weiss, E.B. (1990). Our rights and obligations to future generations for the environment. American Journal of International Law, 84(1), 198-207.

White, L. 1967. 'The historical roots of our ecologic crisis'. Science 155(3767): 1203-1207.

World Commission on Environment and Development, Our Common Future (New York: Oxford University Press, 1987)

Wong, P.T.P. (2016). “Meaning-seeking, self-transcendence, and well-being” in Logotherapy and existential analysis. Proceedings of the Viktor Frankl institute. Vol. 1. ed. A. Betthyany (Cham, CH: Springer), 311-322. 
Yagil, Y. (2015). The Physiology of Empathy: Theoretical and Practical Implications. Encountering Empathy, 3-16.

Yalom, I. 1980. Existential psychotherapy. New York: Basic Books. 